\title{
Morphometric Study of Muscle Fibers in Rats Submitted to Strength Training and Growth Hormone
}

\author{
Estudio Morfométrico de las Fibras Musculares de Ratas Sometidos \\ a Entrenamiento de la Fuerza Muscular y Hormona del Crecimiento
}

\begin{abstract}
Robson Chacon Castoldi ${ }^{1,2}$; Guilherme Akio Tamura Ozaki ${ }^{1}$; Ines Cristina Giometti ${ }^{3}$; Regina Celi Trindade Camargo ${ }^{4}$; Tatiana EmyKoike; ${ }^{4}$ Thiago Alves Garcia ${ }^{4}$; José Carlos Silva Camargo Filho ${ }^{4} \&$ William Dias Belangero ${ }^{4}$
\end{abstract}

CASTOLDI, R. CH.; OZAKI, G. A. T.; GIOMETTI, I. C.; CAMARGO, R. C. T.; KOIKE, T. E.; GARCIA, T. A.; FILHO, J. C. S. C. \& BELANGERO, W. D. Morphometric study of muscle fibers in rats submitted to strength training and growth hormone. Int. J. Morphol., 35(2):472-478, 2017.

SUMMARY: The aim of the present study was to observe the changes in the muscle tissue of rats after application of growth hormone $(\mathrm{GH})$ and performing a strength training protocol (ST). In total, 40 male Wistar rats, 60 days old, were used, divided into four groups: control (C), control and application of GH (GHC), strength training (T), and strength training with the application of GH (GHT). The physical training protocol (PT) was composed of four series of 10 jumps in water, 3x/week, with an overload of $50 \%$ of body weight for four weeks. GH was administered intraperitoneally at a dose of $0.2 \mathrm{IU} / \mathrm{Kg}$ to the GHC and GHT groups and saline (0.9 \% sodium chloride) to the $\mathrm{C}$ and $\mathrm{T}$ groups. After four weeks of PT, the animals were euthanized and samples taken from the Soleus muscle. Histological sections were produced with a thickness of $5 \mathrm{~mm}$ and stained with hematoxylin-eosin (HE) and nicotinamide adenine dinucleotide tetrazolium reductase (NADH-TR). The markings for determining the measurement of the smallest diameter of muscle fibers (MF) were carried out using the software (AuxioVisionRel 4.8-Carl Zeiss ${ }^{\circledR}$ and NIS-Elements D3.0-SP7-Nikon ${ }^{\circledR}$ ). After obtaining the data, the Shapiro-Wilk test for normality was performed and then the nonparametric Kruskal-Wallis with Dunn post-test were used for analysis of MF and the Student $\mathrm{t}$ test for the analysis of intragroup body weights. All procedures adopted a $5 \%$ significance value (p $<0.05$ ) and were performed using the software SPSS 22.0 for Windows ${ }^{\circledR}$. It was observed that both the GH and PT were able to generate

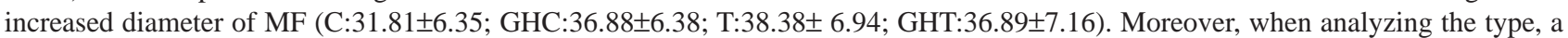
significant increase was found only in the fast twitch MF (C:33.78 \pm 7.78 ; GHC:37.80 \pm 6.03 ; T:38.53 \pm 6.94 ; GHT:37.98 \pm 7.65$)$ when

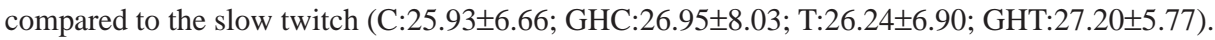

KEY WORDS: Growth hormone; Striated Muscle; Orthopedics; Physical Education and Training; Endocrinology.

\section{INTRODUCTION}

Substances considered anabolic have been used by practitioners of physical activity and high-performance athletes, one of which is somatropin or growth hormone (GH). Released from the anterior pituitary, $\mathrm{GH}$ is considered a potent cell growth stimulator (Fryburg et al., 1991; Ehrnborg \& Rosén, 2008).

GH was first isolated in humans in 1956 by Li et al., (1956), and when used by adults, demonstrated greater retention of nitrogen $(\mathrm{N})$, the element that composes muscle tissue in the form of protein. However, by promoting the growth of muscle tissue, GH has generated conflicts regarding its effects on the performance of athletes in the sports field and anti-doping control, provoking discussions about the tests used for doping detection (Adams, 2000; Barros Neto, 2001;Ambrose, 2004; Ehrnborg \& Rosén).

Despite being banned in the sports field for medical and ethical reasons, GH is well known among athletes and bodybuilders. According to Cruzat et al., (2008), in skeletal muscle, GH has an anabolic effect on protein synthesis, and it is for this reason that physical activity and muscular

\footnotetext{
${ }^{1}$ Faculty of Medical Sciences. Universidade Estadual de Campinas - UNICAMP, Brasil.

${ }^{2}$ Department of Physical Education. Universidade do Oeste Paulista - UNOESTE, Brasil.

${ }^{3}$ Faculty of Veterinary Medicine. Universidade do Oeste Paulista - UNOESTE, Brasil.

${ }^{4}$ Department of Physiotherapy. Universidade Estadual Paulista "Júlio de Mesquita Filho" - UNESP, campus de Presidente Prudente, Brasil.
} 
strength training $(\mathrm{ST})$ produce increased muscle mass, a process called "hypertrophy".

Thus, due to its plastic function, which can adapt after execution, skeletal muscle function suffers adaptations as a result of the performance of training (Fleck \& Kraemer, 1999; Castoldi et al., 2013). In addition, physical performance assessments, such as maximum oxygen consumption (VO2max) and ventilatory threshold, are impaired due to GH deficiency and increased when hormone replacement exists (Widdowson et al., 2009). Although there is no clarity on this information, it is probable that $\mathrm{GH}$ increases the supply of oxygen to muscles during exercise, as well as promoting the use of substrates of fatty acids and glycogen, improving body composition and thermoregulation (Cruzat et al.; Widdowson et al.).

However, indiscriminate use of this hormone can cause side effects, such as aggressiveness, increased or decreased libido, bipolarity, the appearance of acne and skin inflammations, baldness, voice alteration, and acromegaly, among others (Da Silva et al., 2002; Silva \& Lima, 2007). In addition, GH may be a means of triggering cell growth and stimulating neoplasias (Da Silva et al.).

On the other hand, controlled and indicated use of this hormone in recombinant form is an effective method to correct its deficiency in children with delayed growth (Silva \& Lima). Furthermore, in the case of physiological disorders such as Diabetes Mellitus, GH can contribute to an increase in IGF-1 (Leme et al., 2009).

Although GH has already been well studied in various clinical forms, there are few studies related to the use of this type of hormone as an adjunct to physical training, especially for the development of muscle hypertrophy, such as strength training (ST). Thus, the objective of the study was to observe the alterations that occur at the optical microscopic level $(\mathrm{OM})$ in the muscle tissue of rats after application of $\mathrm{GH}$ and the realization of a PT protocol.

\section{MATERIAL AND METHOD}

Animals. In total, 40 male Wistar rats were used, 60 days old, obtained from the Central Animal Laboratory at the University of West Paulista and kept in a vivarium for small rodents at the Veterinary Medicine Department, located on campus II of the institution. They were randomly divided into groups of 05 animals per cage (polyethylene) with a controlled ambient temperature $\left(22+2{ }^{\circ} \mathrm{C}\right)$ and light (light/ dark cycle twelve hours), with free access to food and water (feed for laboratory rats). The present study was approved by the ethics research committee on the use of animals CEUA, approval number 2626.

Physical Training Protocol. The animals were randomly distributed into four groups: Control $(\mathrm{C})[\mathrm{N}=10]$, Control and $\mathrm{GH}(\mathrm{GHC})[\mathrm{N}=10]$, Strength training $(\mathrm{T})$ [ $\mathrm{N}=10]$, and Strength Training with GH $(\mathrm{GHT})[\mathrm{N}=10]$. The training period lasted four weeks.

The animals that received training underwent an adaptation period (one week) to the liquid medium and equipment, with the purpose of reducing the stress generated by the PT, however, without causing significant physiological adaptations. This procedure was carried out as proposed by Manchado et al., (2006) and used by Castoldi et al. The protocol included a weekly increase in the number of jumps, load, and duration of activities, on non-consecutive days (1x10; 2x10; 3x10).

\section{Experimental Groups}

C Group: the animals remained in their cages, with free access to food and water (ad libitum). In addition, the same volume of saline $(0.9 \%$ sodium chloride in water) was applied as the groups receiving $\mathrm{GH}$.

GHC Group: the animals remained in their cages, with free access to food and water. The animals received 0.2 International Units per kilogram of body weight $(0.2 \mathrm{IU} / \mathrm{Kg})$ of GH (Saizen $\left.{ }^{\circledR}\right)$, intraperitoneally, three times per week.

T Group: the animals were subjected to four series of 10 water jumps, performed three times a week in a cylindrical PVC container, $50 \mathrm{~cm}$ diameter and $38 \mathrm{~cm}$ high (adapted to be used as a pool for jumps in water). The water was kept warm throughout training with an average temperature of $30^{\circ} \mathrm{C}( \pm 1)$.

The overload utilized corresponded to $50 \%$ of the body weight of each animal, corrected weekly, accommodated in the anterior chest through a vest (Fig. 1), as proposed by De Malheiro et al., (2009) and used by Castoldi et al., and Castoldi et al., (2015).

Prior to each training session, the animals received the application of saline ( $0.9 \%$ sodium chloride in water), intraperitoneally, in a similar manner to the GHT group.

GHT Group: The animals underwent the same training as the group described above ( $\mathrm{T}$ group), although, in this case, the animals received 0.2 International Units per kilogram body weight $\left(0.2 \mathrm{IU} / \mathrm{Kg}\right.$ ) of GH (Saizen $\left.{ }^{\circledR}\right)$, intraperitoneally, before all training sessions. 


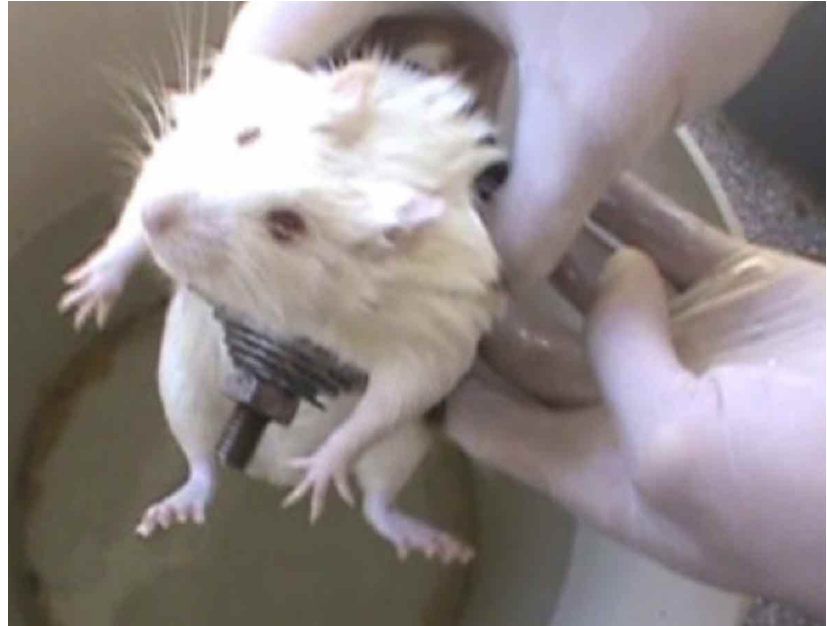

Fig. 1. Muscular strength training protocol.

Striated Skeletal Muscle. At the end of the experimental period, the animals were anesthetized with ethyl ether and then euthanized by exsanguination through the cardiac puncture method. Next, the soleus muscle was extracted and immersed in n-hexane. After this procedure, the samples were cooled in liquid nitrogen and stored in an ultra-low temperature freezer $\left(-80^{\circ} \mathrm{C}\right)$ (Camargo Filho et al., 2011).

Subsequently, $5 \mu \mathrm{m}$ sections were produced transversely in the ventral portion of the muscle in a microtome cryostat at $-20{ }^{\circ} \mathrm{C}$, collected on slides and then stained with hematoxylin-eosin (HE) for an overview of the structure of the muscles, with increases in the order of 10x.

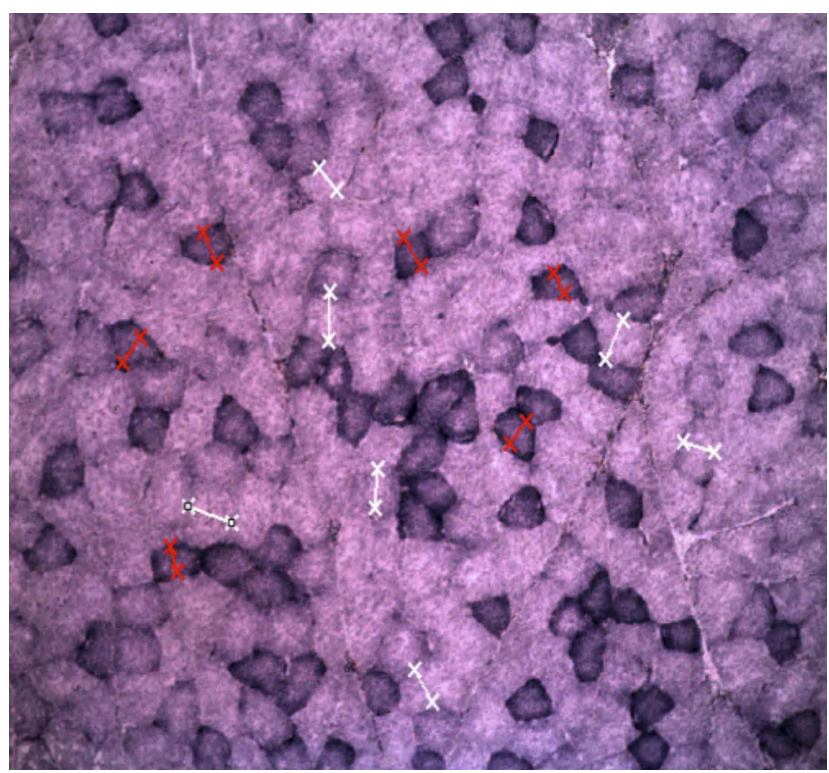

Fig. 2. Measurement of the smallest diameter of muscle fibers. Cuts from the reaction of nicotinamide adenine dinucleotide tetrazolium reductase (NADH-TR), magnified 10X.
To analyze the type of muscle fibers, the reaction of nicotinamide adenine dinucleotide tetrazolium reductase (NADH-TR) was utilized, according to the model proposed by Camargo Filho et al., and used by and Castoldi et al.

Optical microscopy. The cuts subjected to stains and histochemical reactions were observed in normal and polarized light and photomicrographed in a microscope, brand Nikon $^{\circledR}$, model H550S. For analysis of the images, an Infinity 1 camera was used. The markings for determining the measurement of the smallest diameter of the muscle fibers were performed using the software (AuxioVisionRel 4.8 - Carl Zeiss ${ }^{\circledR}$ e NIS-Elements D3.0 SP7 - Nikon ${ }^{\circledR}$.

The measurement was carried out by demarcating the smallest diameter passing through the center of the muscular fibers (Fig. 2). Ten cuts were produced and 120 muscle fibers measured per animal in accordance with the protocol established by Dal Pai (1982).

Statistical Analysis. The Shapiro-Wilk normality test was performed to verify the distribution of values in the Gaussian curve. Normality was not verified for the variables corresponding to the muscle diameter and thus, the nonparametric Kruskal-Wallis test with the Dunn post test was used.

As for the body mass variable, normality was verified and thus the dependent Student t test was used for the intragroup analysis, in the pre and post-training moments. All procedures adopted a significance level of $5 \%(\mathrm{p}<0.05)$ and the calculations were performed using the software SPSS 22.0 for Windows ${ }^{\circledR}$.

\section{RESULTS}

Body mass increased significantly ( $\mathrm{p}<0.05$ ) over time in all groups (Fig. 3); the GHT group presented higher values for this variable.

From the analysis of muscle fibers, distinct morphologies were observed in the different groups of animals, both in the analyses obtained from the HE staining and in the NADH-TR reaction (Figs. 4 and 5 respectively).

Thus, in general, when observing the HE cuts, an increase in the MF diameter was noted in all groups, independent of the treatment. Thus, both the application of $\mathrm{GH}$, the realization of PT, and both combined, were capable of generating hypertrophy (Figs 4B, 4C and 4D). 


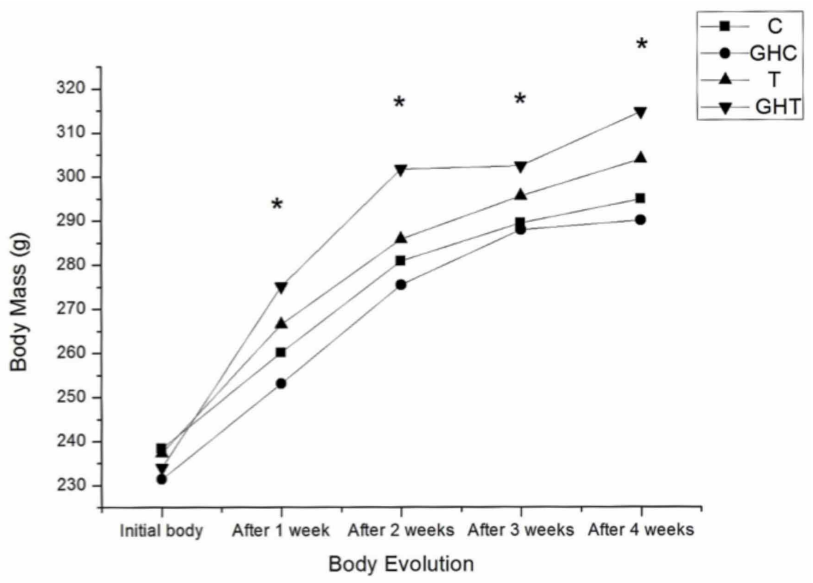

Fig. 3. Analysis of body mass in the pre- and post-training moments. Legend: (A) Control group. (B): Control and GH group. (C): Strength Training Group (D): Strength Training and GH group. (*): Comparison of means, pre and post experimental moments through the Student t test $(\mathrm{p}<0.05)$.

After the analysis through the NADH-TR reaction, it was possible once again to identify an increase in $\mathrm{MF}$ diameter in all experimental groups ( $\mathrm{GH}, \mathrm{PT}$, and $\mathrm{GH}+\mathrm{PT})$. However, in this case, only the FMCR demonstrated an increase in diameter (Figs. 5B, 5C and 5D).

In addition, after performing the morphometric analyzes (measurements of diameter) it was observed that the groups of animals responded differently to treatment (Figs.
6, 7 and 8). Thus, it is possible to verify that both the $\mathrm{GH}$ and PT were able to generate increased MF diameter (C: $31.81 \pm$ 6.35; GHC: $36.88 \pm 6.38$; T: $38.38 \pm 6$, 94; GHT: $36.89 \pm$ 7.16) $(\mathrm{p}<0.05)$.

Furthermore, when analyzing the type, a significant increase ( $\mathrm{p}<0.05)$ was observed only in the fast twitch MF (C: $33.78 \pm 7.78$; GHC: $37.80 \pm 6.03$; T: $38.53 \pm 6.94$; GHT: $37.98 \pm 7.65)$ when compared to the slow twitch (C: $25.93 \pm$ 6.66; GHC: $26.95 \pm 8.03$; T: $26.24 \pm 6.90$; GHT: $27.20 \pm$ $5.77)$.

It was verified that when analyzing the fibers in a general manner through the HE staining method, all experimental groups demonstrated hypertrophy of muscle fibers. Thus, regardless of the treatment (PT or GH), there was an increase in the diameter of muscle fibers $(\mathrm{p}<0.05)$.

Slow twitch muscle fibers were also analyzed (FMCL), through the NADH-TR reaction (Fig. 7). In this case, it was found that although there was an increase in the diameter of muscle fibers (MF), principally in the GHC and GHT groups, this result did not demonstrate statistical significance $(\mathrm{p}>0.05)$.

However, when analyzing the fast-twitch muscle fibers (FMCR) a significant increase was observed in all the experimental groups $(\mathrm{p}<0.05)$, regardless of the treatment (Fig. 8).

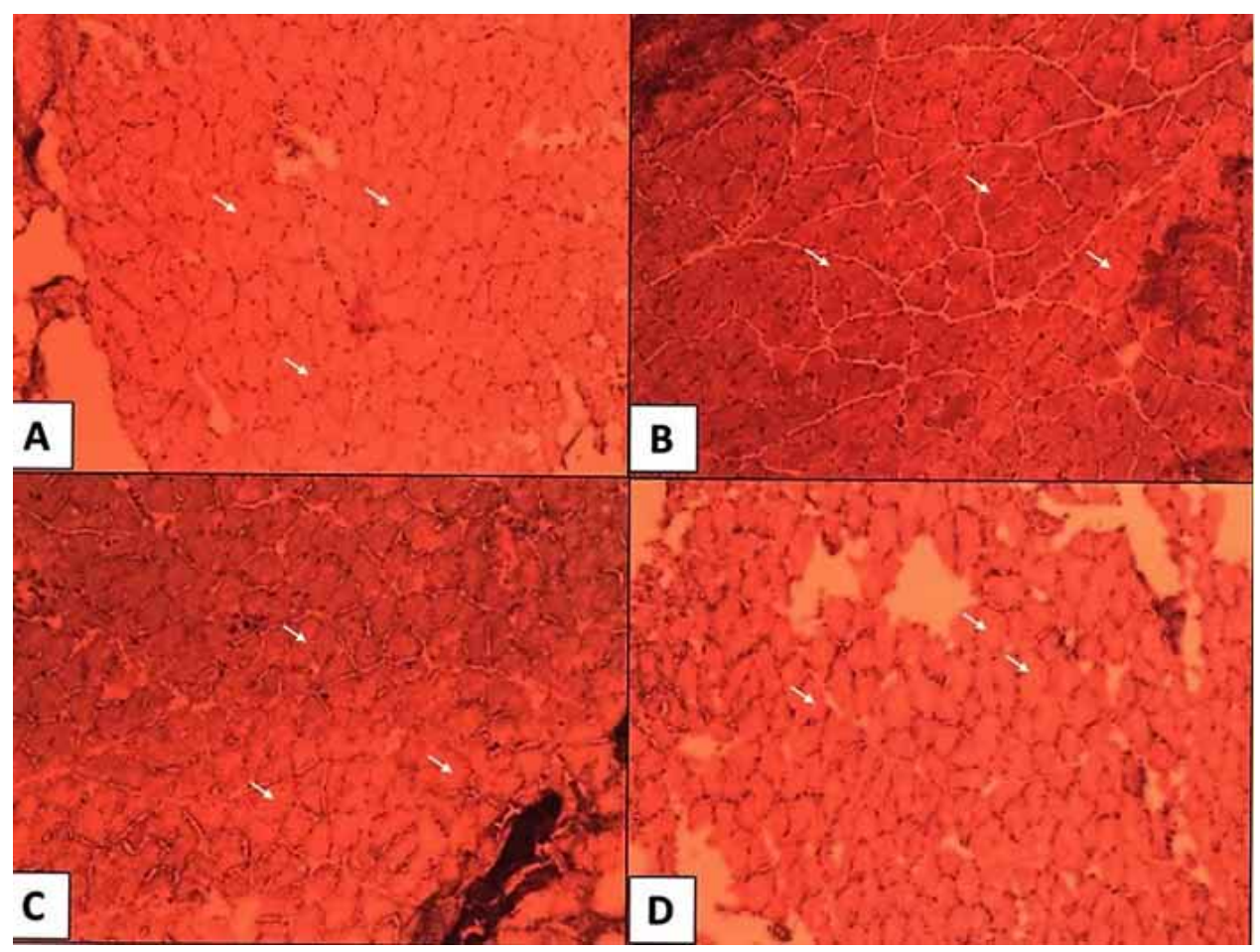

Fig. 4. Staining with hematoxylin and eosin (HE) of muscle fibers at $10 \mathrm{X}$ magnification. (A) Control group. (B): Control and GH group. (C): Strength Training group. (D): Strength training and GH group. Arrows indicate muscle fibers. 


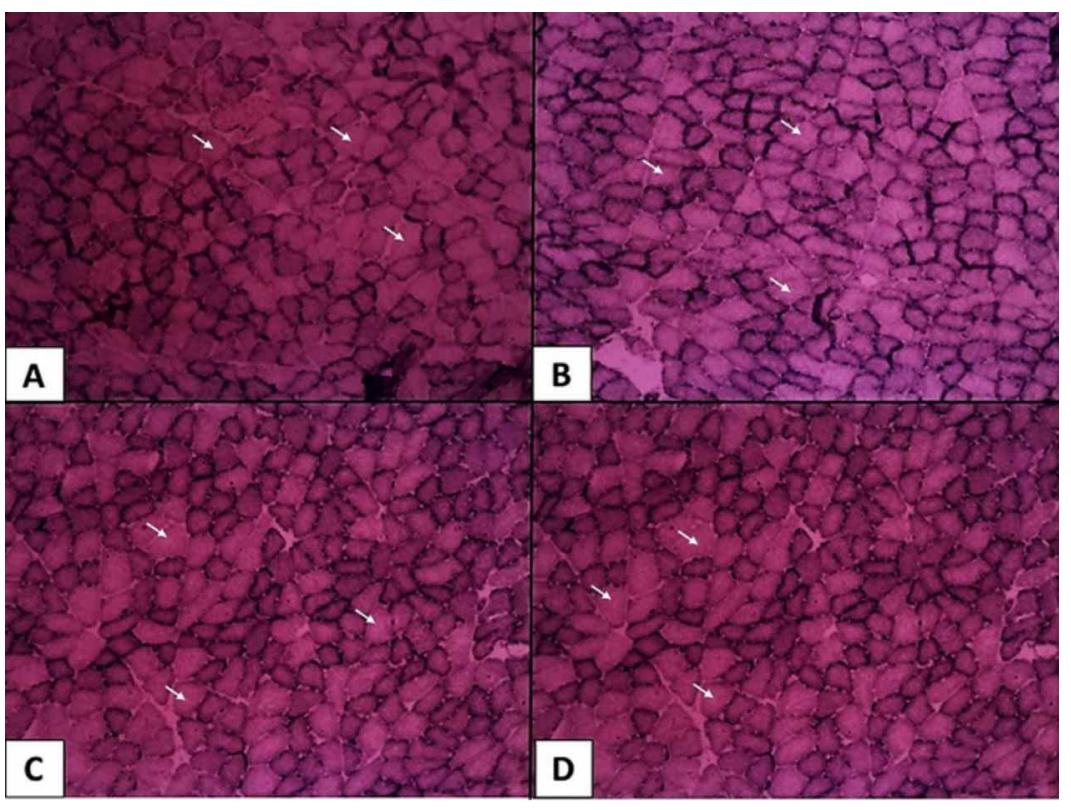

Fig. 5. Analysis of fast and slow twitch muscle fibers through the nicotinamide adenine dinucleotide tetrazolium reductase reaction (NADH-TR). Legend: (A) Control group. (B): Control and GH group. (C): Strength training group. (D): Strength training and $\mathrm{GH}$ group. Arrows indicate muscle fibers.

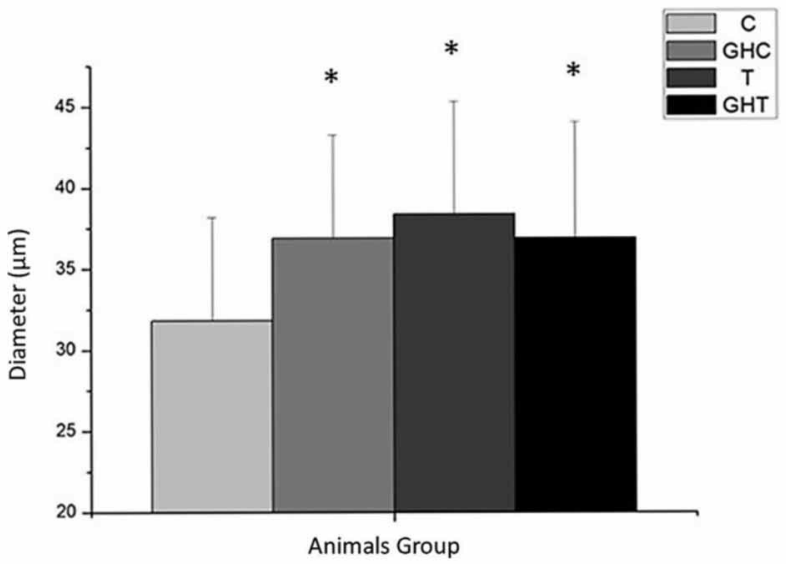

Fig. 6. Diameter of Muscle Fibers through the staining with hematoxylin and eosin (HE). Legend: (C) Control group. (GHC): Control and GH group. (T): Strength training group. (GHT): Strength training and GH group. (*). Statistical difference when compared to the $\mathrm{C}$ group. Kruskal-Wallis test with Dunn post test $(\mathrm{p}<0.05)$.

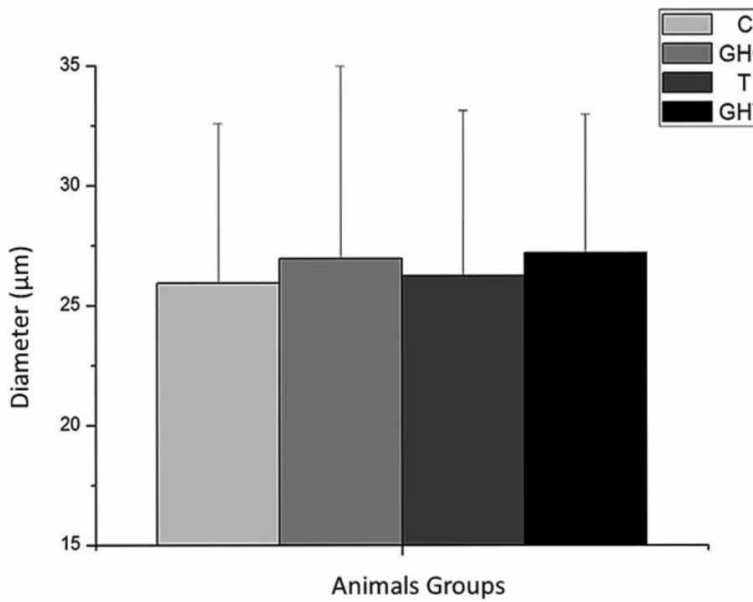

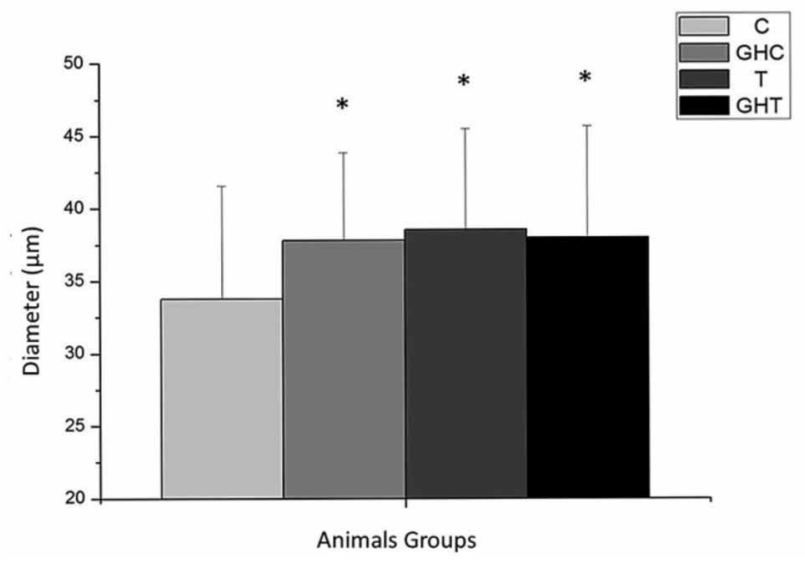

Fig. 8. Diameter of fast twitch muscle fibers through the nicotinamide adenine dinucleotide tetrazolium reductase reaction (NADH-TR). Legend: (C) Control group. (GHC): Control and GH group. (T): Strength training group. (GHT): Strength training and GH group. (*): Statistical difference when compared to the $\mathrm{C}$ group. Kruskal-Wallis test with Dunn post test $(\mathrm{p}<0.05)$.
Fig. 7. Diameter of slow twitch muscle fibers through the nicotinamide adenine dinucleotide tetrazolium reductase reaction (NADH-TR). Legend: (C) Control group. (GHC): Control and GH group. (T): Strength training group. (GHT): Strength training and GH group. Kruskal-Wallis test $(\mathrm{p}>0.05)$. 


\section{DISCUSSION}

The aim of this study was to investigate the effects of strength training (PT) and growth hormone $(\mathrm{GH})$ on the diameter of muscle fibers (MF) of the Soleus muscle of Wistar rats. The measurements were performed from the smallest diameter of the muscle fibers and specific measures of fast (FMCR) and slow twitch fibers (FMCL) were also carried out. An increase in the diameter of MF was also observed in the GH and PT groups (Fleck \& Kraemer; Castoldi et al.), in a general manner and in accordance with the contraction specificity (FMCR and FMCL). It is known that the use of water jumps can recover volume of muscle tissue lost after immobilization (Antunes et al., 2012). In addition to causing hypertrophy of muscle fibers (Moret et al., 2013), this activity acts systemically, increasing the mobilization of glucose, free fatty acids (FFA), and corticosterone to perform muscle contraction and reduce muscle glycogen, hepatic, and blood insulin concentrations (Rogato et al., 2003).

It was observed that the FMCR presented a higher increase in diameter than the FMCL. This difference can be explained by the type of physical activity imposed on the animals, which is characterized by stimuli with greater contraction force for short periods of time (Fleck \& Kraemer; Castoldi et al.). Differently, the FMCL adapt better to the application of stimuli with less force of contraction and performed for long periods of time, as in the specific case of aerobic training. Specificity of physical exercise can increase cellular organelles, such as mitochondria, and thus increase the intramuscular energy substrates and their improved utilization in the aerobic metabolism (Castoldi et al.).

In the present study, there was no significant adaptation in the experimental groups (GHC, T, and GHT), compared with the $\mathrm{C}$ group ( $\mathrm{p}>0.05$ ), although these demonstrated a slight increase in the mean smallest diameter of MF. This finding confronts those presented by Castoldi et al. who verified an increase in both types of muscle fibers (fast and slow), in 14 weeks of PT, with a duration greater than the one adopted in the present study. Moreover, Castoldi et al. analyzed the medial gastrocnemius muscle, which has a predominance of glycolytic fibers when compared to the Soleus muscle used in the present research. This may explain the lower adaptation when compared to the study by Castoldi et al. Future research, analyzing different muscle groups, is likely to add to the results observed in the present study.

In addition to the PT, the present study examined the alterations caused by GH. A hypertrophic effect generated by the hormone was observed, regardless of the PT. According to Cruzat et al. GH has anabolic effects directly related to protein metabolism and may contribute to muscle growth. This may explain the hypertrophic process in the analyzed animals.

The exact mechanism of action of $\mathrm{GH}$ in muscle hypertrophy is not yet fully understood (Cruzat et al.) A study in humans measured the release of growth factor (IGF-1) in the blood of two groups of individuals, the first with no experience (UT) and the second with experience in practicing resistance training (RT). It was found that after performing a session of squatting exercises, there was an increase in the release of growth factor (IGF-1), in both groups, which prevailed in the UT group, in different periods after completion, in a way that suggested apparent adaptation in hormonal regulation to the performance of resistance training (Rubin $e t$ al., 2005).

However, when the two methods were used jointly (GHT group), it was observed that the hypertrophic process did not occur more strongly when compared with the independent groups (GHC and T). This finding may be explained by the physiological limit of the tissue or animal, which takes into account the tissue adaptation limit regulated by myostatin, thus preventing hypertrophy occurring in an uncontrolled manner (Yamada et al., 2012).

Thus, this study contributes to the literature by evaluating the effects of PT and the use of $\mathrm{GH}$ on the morphometry of striated skeletal muscle of Wistar rats. However, some limitations should be considered, such as the lack of measurement of blood hormone dosage and protein quantification in muscle tissue. In this sense, research involving PT and GH, using analysis of gene expression and growth factors, could contribute to the findings to date.

CONCLUSION. It was concluded that when analyzing the sections by OM, stained with hematoxylin, all experimental groups demonstrated increased MF diameter, independent of GH administration, performing PT, or both. However, when verifying the slides stained by the reaction of NADHTR, only the FMCR demonstrated a significant increase.

CASTOLDI, R. CH.; OZAKI, G. A. T.; GIOMETTI, I. C.; CAMARGO, R. C. T.; KOIKE, T. E.; GARCIA, T.A.; FILHO, J. C. S. C. \& BELANGERO, W. D. Estudio morfométrico de las fibras musculares de ratas sometidas a entrenamiento de la fuerza muscular y hormona del crecimiento. Int. J. Morphol., 35(2):472478, 2017.

RESUMEN: El objetivo de la investigación fue observar las modificaciones en tejido muscular esquelético de ratas después de la aplicación de la hormona del crecimiento $(\mathrm{GH})$ y posterior entrenamiento de fuerza muscular (EFM). Fueran utilizadas 40 ratas 
Wistar, con 60 días de edad, distribuidas en: control (C), control y aplicación de la hormona del crecimiento (GHC), entrenamiento de fuerza muscular (T), y entrenamiento de fuerza muscular y hormona del crecimiento (GHT). El protocolo de entrenamiento (PT) fue compuesto por cuatro series de diez saltos acuáticos, 3x/semana, con sobrecarga de $50 \%$ del peso corporal, por cuatro semanas. $\mathrm{El} \mathrm{GH}$ fue aplicado de forma intraperitoneal con una dosis de $0,2 \mathrm{UI} /$ kg en grupos GHC y GHT y solución salina $(0,9 \%$ clorhidrato de sodio) en grupos C y T. Después de cuatro semanas del PT, los animales fueron sacrificados y retirados los músculos sóleos. Se realizaron cortes de $5 \mu \mathrm{m}$ los que fueron coloreados con Hematoxilina y Eosina (HE), posteriormente fueron sometidos a reacción con nicotinamida adenina dinucleotide tetrazolium reductasa (NADH-TR). Después de la obtención de los datos, fue utilizado la prueba del Shapiro-Wilk para la verificación de la normalidad de los datos y se usó el ensayo de Kruskal-Wallis con pos verificación del Dunn para análisis de las fibras musculares (FM) y prueba t del Student para la análisis del peso corporal entre los grupos. Todos los procedimientos fueron establecidos con valor de la significancia de $5 \%(\mathrm{p}<0,05)$ y realizados con el software SPSS 22.0 for Windows ${ }^{\circledR}$. Fue verificado que tanto lo GH cuanto lo PT fueran capaces de proporcionar el aumento en el diámetro de

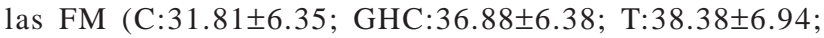
GHT:36.89 \pm 7.16). En relación al tipo de fibras se observó aumento significativo solamente en las FM de contracción rápida

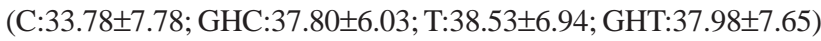
cuando se comparó con las FM de contracción lenta (C:25.93 \pm 6.66 ; GHC:26.95 \pm 8.03 ; T:26.24 $\pm 6.90 ;$ GHT:27.20 \pm 5.77$)$.

PALABRAS CLAVE: Hormona del Crecimiento; Músculo Estriado; Ortopedia; Educación y Entrenamiento Físico; Endocrinología.

\section{REFERENCES}

Adams, G. R. Insulin-like growth factor in muscle growth and potential abuse by athletes. Br. J. Sports Med., 34:412-13, 2000.

Ambrose, P. J. Drug use in sports: a veritable arena for pharmacists. J. Am. Pharm. Assoc., 44(4):501-14, 2004.

Antunes, J. S.; Karvat J.; Meireles A.; Rocha B. P.; Rosa, C. T.; Silva L. I. \& Bertolini, G. R. F. Exercício resistido em meio aquático para ratos Wistar submetidos a trauma em tendão: avaliação da nocicepção e edema. Rev. Dor., 13(1):55-8, 2012.

Barros Neto, T. L. De. A controvérsia dos agentes ergogênicos: estamos subestimando os efeitos naturais da atividade física? Arq. Bras. Endocrinol. Metab., 45(2):121-22, 2001.

Camargo Filho, J. C. S.; Garcia, B. C.; Kodama, F. Y.; Bonfim, M. R.; Vanderlei, L. C. M., Ramos, E. M. C.; Camargo, R. C. T.; Padulla, S. A. T. \& Maeda, J. K. Efeitos do exercício aeróbio no músculo esquelético de ratos expostos à fumaça de cigarro. Rev. Bras. Med Esporte, 17(6):416-19, 2011.

Castoldi R. C.; Teixeira G. R.; De Mello Malheiro, O. C.; Camargo, R. C. T.; Belangero, W. D. \& Camargo Filho J. C. S. Effects of 14 Weeks Resistance Training on Muscle Tissue in Wistar Rats. Int. J. Morphol., 33(2):446-51, 2015.

Castoldi, R. C.; Camargo, R. C. T.; Magalhães, A. J. B.; Ozaki, G. A. T.; Kodama, F. Y.; Oikawa, S. M.; Papoti, M. \& Camargo Filho, J. C. S. Concurrent training effect on muscle fibers in Wistar rats. Motriz Rev. Educ. Fís., 19(4):717-23, 2013.
Cruzat, V. F.; Júnior, J. D.; Tirapegui, J. \& Schneider, C. D. Hormônio do crescimento e exercício físico: considerações atuais. Rev. Bras Ciênc. Farm., 44(4):549-62, 2008

Da Silva, P. R. P.; Danielski, R. \& Czepielewski, M. A. Esteróides anabolizantes no esporte. Rev. Bras. Med. Esporte., 8(6):235-43, 2002.

Dall Pai, V.; Costa, I.R.S. \& Curi, P.R. Postnatal Growth of fibreson M. gracilis (parscaudalis) in bothsexesofrat. Anat. Anz., 152(1):53-9, 1982.

De Mello Malheiro, O. C.; Giacomini, C. T.; Justulin, L. A. Jr.; Delella, F. K.; Dal-Pai-Silva, M. \& Felisbino, S. L. Calcaneal tendon regions exhibit different mmp-2 activation after vertical jumping and Treadmill Running. Anat. Rec., 292(10):1656-62, 2009.

Ehrnborg, C. \& Rosén, T. Physiological and pharmacological basis for the ergogenic effects of growth hormone in elite sports. Asian J. Androl., 10(3):373-83, 2008.

Fleck, S. J. \& Kraemer, W. J. Fundamentos do Treinamento de Força Muscular. Artmed, 1999.

Fryburg, D. A.; Gelfand, R. A. \& Barrett, E.J. Growth hormone acutely stimulates forearm muscle protein synthesis in normal humans. Am. J. Physiol., 260(3):499-504, 1991.

Leme, J. A. C. A.; Silveira, R. F.; Gomes, R. J.; Moura, R. F.; Sibuya, C. A.; Mello, M. A. R. \& Luciano, E. Long-term physical training increases liver IGF-I in diabetic rats. Growth Hormone IGF Res., 19(3):262-66, 2009.

Li, C. H. \& Papkoff, H. Preparation and properties of growth hormone from human and monkey pituitary glands. Science, 124:1293-4, 1956.

Manchado, F. B.; Gobatto, C. A., Contarteze, R. V. L., Papoti, M. \& Mello, M.A.R. Máxima fase estável de lactato é ergômetro-dependente em modelo experimental utilizando ratos. Rev. Bras. Med. Esporte, 12(5):259-62, 2006

Moret, D. G.; Castoldi, R. C.; De Araújo, R. G.; Spagnol, A. R.; Papoti, Marcelo.; Camargo Filho, J. C. Silva. \& De Mello Malheiro, O. C. Análise morfológica do músculo gastrocnêmio medial de ratos submetidos a um protocolo de treinamento concorrente. Rev. Bras. Ciênc. Esporte. 35(3):587-97, 2013.

Rogatto, G. P.; Faria, M. C. \& Luciano, E. Respostas metabólicas agudas de ratos Wistar ao exercício intermitente de saltos. Rev. Bras. Ativ. Fís. Saúde. 6(2):39-46, 2001.

Rubin, M. R.; Kraemer, W. J.; Maresh, C. M.; Volek, J. S.; Ratamess, N. A.; Vanheest, J. L.; Silvestre, R.; French, D. N.; Sharman, M. J.; Judelson, D. A.; Gómez, A. L.; Vescovi, J. D. \& Hymer, W. C. High-affinity growth hormone binding protein and acute heavy resistance exercise. Med. Sci. Sports Exerc., 37(3):395-403, 2005.

Silva, K. G. \& Lima, R. M. Prevalência da utilização de anabolizantes pelos estudantes de Educação Física na cidade de Campos dos Goytacazes. Vértices, 9(1):123-48, 2007.

Widdowson, W. M.; Healy, M. L.; Sönksen, P. H. \& Gibney, J. The physiology of growth hormone and sport. Growth Hormone IGF Res., 19(4):308-19, 2009.

Yamada, A. K.; Verlengia, R.; \& Bueno Junior, C. R. Myostatin: genetic variants, therapy and gene doping. Braz. J. Pharm. Sci., 48(3):369-77, 2012.

Corresponding author:

Robson Chacon Castoldi

Universidade Estadual Paulista - UNESP

Rua Roberto Simonsen, 305

19060-900 - P. Prudente, SP

BRAZIL

E-mail: castoldi_rc@yahoo.com.br

Received: 21-09-2016

Accepted: 05-01-2017 